\title{
PENGGUNAAN CALENDULA OFFICINALIS SEBAGAI TERAPI PENYEMBUHAN LUKA DI KULIT
}

\author{
Hillery Sihotang \\ Fakultas Kedokteran, Universitas Lampung, Jl. Prof. DR. Ir. Sumatri Brojonegoro No.1, Gedong Meneng, \\ Kec. Rajabasa, Kota Bandar Lampung, Lampung, Indonesia 35145 \\ hilleryhs1706@gmail.com (+6282177759966)
}

\begin{abstract}
ABSTRAK
Luka merupakan salah satu masalah medis yang berkembang secara global yang membutuhkan terapi perawatan kulit yang khusus. Calendula officinalis memiliki banyak sifat farmakologis, seperti digunakan untuk pengobatan gangguan kulit, nyeri dan juga sebagai bakterisida, antiseptik dan anti-inflamasi. Literatur ini bertujuan untuk mengetahui lebih lanjut mengenai keefektifitasan Calendula officinalis dalam penyembuhan luka dalam uji klinis manusia. Penelitian ini merupakan literatur review yang melibatkan berbagai sumber pustaka dengan kata kunci yang digunakan 'calendula officinalis dan terapi penyembuhan luka di kulit' dengan tahun terbit antara 2008 - 2019. Literatur berupa 15 jurnal dibaca kemudian dicermati, selanjutnya dilakukan analisis terhadap hasil/temuan dan pembahasan penelitian. Ada beberapa bukti efektivitas penggunaan ekstrak Calendula officinalis untuk manajemen luka pada kulit. Data yang disajikan dalam ulasan ini mendukung studi lanjutan tentang penggunaan salep yang mengandung ekstrak Calendula officinalis selama penyembuhan luka. Calendula officinalis dapat mencegah komplikasi luka karena mengandung metabolit sekunder, yang dapat mendukung penyembuhan luka.
\end{abstract}

Kata kunci: calendula officinalis; luka di kulit; terapi penyembuhan luka di kulit

\section{THE USE OF CALENDULA OFFICINALIS AS SKIN WOUND HEALING TREATMENT}

\begin{abstract}
Wounds present a significant global growing medical problem requiring specialized care in skin treatment. Calendula officinalis has many pharmacological properties, such as being used for the treatment of skin disorders, pain and also as a bactericidal, antiseptic and antiinflammatory. This literature review aims to determine Calendula officinalis's effectiveness in wound healing in human clinical trials. This research is a literature review involving as many literature sources with the keywords used 'calendula officinalis and skin wound healing treatment' with year of published between 2008 up to 2019. About 15 journals are read and examined, then an analysis of the content in the results/findings and discussions is carried out. The effectiveness of Calendula extract use for skin wound healing treatment was found in some evidences. The data presented in this review supports continued study of the use of ointments containing calendula extract during wound healing. Calendula may prevent wound complications since the flower contains secondary metabolites, which may support wound healing.
\end{abstract}

Keywords: calendula officinalis; wound ; skin wound healing treatment

\section{PENDAHULUAN}

Luka merupakan salah satu masalah medis yang berkembang secara global yang membutuhkan terapi perawatan kulit yang khusus. Luka memiliki patofisiologi yang beragam, dengan 
klasifikasi yang kelompokkan menurut perjalanan waktu, dan dibagi lagi menjadi luka akut, kronis, dan luka bakar. Perkembangan penyembuhan luka telah dibagi menjadi tiga fase yang kadang overlapping yaitu fase pertama adalah inflamasi, fase kedua adalah proliferasi, dan fase terakhir adalah maturasi (Givol et al., 2019). Luka akut melewati semua fase dan mencapai pemulihan lengkap, sesuai dengan mekanisme cedera dan ukuran lesi, biasanya dalam 5 sampai 10 hari (Velnar, 2009). Luka kronis membutuhkan waktu untuk sembuh yang lebih lama dari yang diharapkan, biasanya lebih dari 4 minggu (Izadi, 2005). Luka bakar dicatat sebagai kelompok terpisah karena mereka berbeda dalam patofisiologi dan perjalanan alami dari luka kulit lainnya (Givol et al., 2019).

Calendula officinalis adalah tanaman kebun yang umum digunakan secara medis di Eropa, Cina, Amerika Serikat, dan India. Milik keluarga Asteraceae memiliki banyak nama umum yang digunakan termasuk Marigold Afrika, Calendula, Common Marigold, Garden Marigold, Marigold, Pot Marigold, Zergul di India, Butterblume di Jerman, Chin Chan Ts'ao di Cina, Galbinele di Rumania, dan Ringblomma di Swedia (Muley, 2009). Calendula tumbuh setinggi $60 \mathrm{~cm}$ dan menghasilkan bunga kuning atau oranye besar. Ini digunakan secara topikal sebagai obat antiinflamasi alami dan untuk penyembuhan luka dan ulser kaki. Dosis yang biasanya digunakan adalah 2-4 ml tingtur yang diencerkan menjadi 250 sampai dengan $500 \mathrm{ml}$ dengan air atau 2-5 g herba dalam sekitar $100 \mathrm{~g}$ salep (Re at al., 2009). Penggunaan topikal lainnya termasuk pengobatan untuk derajat 1 luka bakar, memar, bisul, dan ruam (Shafeie, 2015).
Calendula officinalis memiliki banyak sifat farmakologis. Hal ini digunakan untuk pengobatan gangguan kulit, nyeri dan juga sebagai bakterisida, antiseptik dan anti-inflamasi. Fraksi butanol dari Calendula officinalis memiliki sifat bebas yang signifikan genetik dan lingkungan, tetapi peningkatan prevalensi miopia selama abad terakhir di masyarakat tertentu pemulungan radikal dan aktivitas antioksidan. Bunga Calendula officinalis dipercaya bermanfaat dalam mengurangi peradangan, penyembuhan luka, dan sebagai antiseptik, digunakan untuk mengobati berbagai penyakit kulit, mulai dari borok kulit hingga eksim. Secara internal Calendula officinalis telah digunakan untuk sakit maag dan peradangan. Flavonoid, yang ditemukan dalam jumlah tinggi di Calendula officinalis, bertanggung jawab atas aktivitas antiinflamasinya; saponin triterpen mungkin juga penting. Calendula officinalis diketahui juga mengandung karotenoid yang mempunyai fungsi yang lain (Shafeie, 2015).

Pada tahun 2008 terdapat tinjauan naratif dilakukan pada penggunaan Calendula officinalis dalam penyembuhan luka dalam uji klinis manusia. Ulasan ini menilai efektifitas Calendula officinalis dalam penyembuhan luka dan hanya menyertakan bukti dari uji klinis manusia. Karena kurangnya studi pada manusia yang tersedia pada waktu itu, tinjauan difokuskan pada berbagai sifat yang berguna untuk terapi penyembuhan luka. Antiinflamasi, antibakteri, antioksidan, analgesik, dan efek umum pada penyembuhan luka). Karena beberapa studi praklinis in vivo dan uji klinis manusia pada efek Calendula pada penyembuhan luka telah 
diterbitkan, tinjauan sistematis saat ini dilakukan untuk menilai pengetahuan terkini yang dikumpulkan pada hewan dan manusia dengan lesi kulit yang diobati dengan ekstrak calendula sebagai monoterapi dan dibandingkan untuk mengontrol selama penyembuhan luka in vivo (Leach, 2008).

Meskipun studi klinis adalah standar emas untuk membuktikan effikasinya, situasinya bermasalah terutama untuk phytomedicines. Seringkali, tidak mungkin untuk mengajukan paten dan, oleh karena itu, studi klinis yang mahal tidak bermanfaat bagi perusahaan. Penelitian dengan hewan atau sel dilakukan yang dapat memberikan data awal. Beberapa penelitian tikus yang meneliti sifat penyembuhan luka telah dilakukan. Meskipun penelitian Kloucek-Popova et al. menggunakan tikus telah sering dikutip sebagai contoh sukses evaluasi sifat penyembuhan luka, penelitian ini tidak memenuhi standar saat ini. Sifat penyembuhan luka terbaik diperoleh dengan kombinasi ekstrak air alkohol, ekstrak air dan allantoin. Barubaru ini, luka pada tikus yang diobati dengan emulsi fase gel pipih (LPG) yang dibuat dari: Calendula officinalis minyak benar-benar kembali epitel dalam waktu 14 hari, berbeda dengan kelompok formulasi atau kontrol (Nicolaus et al., 2017). Literatur review ini bertujuan untuk mendapatkan pemahaman yang lebih baik tentang sifat penyembuhan luka dari tanaman obat tradisional Calendula officinalis.

\section{METODE}

Artikel ini merupakan studi literature review, yang menyajikan kembali materi yang diterbitkan sebelumnya, dan melaporkan fakta atau analisis baru. Penelusuran sumber pustaka dalam artikel ini hanya melalui database PubMed. Penelitian ini merupakan literatur review yang melibatkan berbagai sumber pustaka dengan kata kunci yang digunakan 'calendula officinalis dan terapi penyembuhan luka di kulit' dengan tahun terbit antara 2008-2019. Literatur berupa 15 jurnal dibaca kemudian dicermati, selanjutnya dilakukan analisis terhadap hasil/temuan dan pembahasan penelitian. Setelah itu dilakukan koding terhadap hasil/temuan dan pembahasan jurnal yang telah dilakukan ulasan berdasarkan inti dari penelitian tersebut yang dilakukan lalu membahas apa saja yang telah ditemukan, perbedaan maupun persamaan dari jurnal-jurnal tesebut untuk menarik suatu kesimpulan.

\section{HASIL}

Hasil penelitian Shafeie, dkk pada tahun 2015 dapat ditemukan bahwa penerapan gel bunga Calendula officinalis memiliki efek positif yang dapat diabaikan pada tahap awal penyembuhan luka pada penyembuhan luka kutaneous yang diinduksi secara eksperimental pada tikus. Namun, gel 7\% menghasilkan keselarasan jaringan yang lebih baik, kolagen diferensiasi dan pematangan fibril, sedangkan gel $10 \%$ dan $5 \%$ menunjukkan hasil yang lebih baik pada kelompok kontrol dan plasebo, sehingga gel 7\% lebih efektif, terutama untuk empat belas hari pertama karena luka memiliki penutup yang lebih sedikit dan gel ini memiliki efek toksik yang lebih sedikit (Shafeie, 2015).

Penelitian lain yaitu penelitian berkontribusi pada pemahaman yang lebih baik tentang sifat penyembuhan luka dari Calendula officinalis diamati dalam hidup. Dalam model berbasis sel kami, kami memberikan bukti bahwa ekstrak lipofilik (HE) dan hidrofilik (EE) dibuat dari Calendula officinalis 
mungkin berdampak pada fase inflamasi dan fase pembentukan jaringan baru, dan di sini pembentukan jaringan granulasi. Namun, efektifitas dari senyawa masih menjadi bahan penelitian. Triterpen dalam ekstrak lipofilik kemungkinan memainkan peran kecil, tetapi karotenoid atau produk degradasinya mungkin lebih relevan, yang perlu dibuktikan dalam penelitian selanjutnya (Nicolaus et al., 2017).

Hasil penelitian ditemukan bahwa ekstrak Calendula officinalis dikaitkan dengan signifikannya secara statistik tidak efektif untuk mempercepat penyembuhan luka di kulit sesuai dengan hasil yang diukur. Penilaian histologis menunjukkan peningkatan angiogenesis dan komposisi kolagen yang lebih padat dalam jaringan granulasi membentuk kelompok perlakuan calendula dibandingkan dengan kontrol. Kelompok perlakuan juga menunjukkan penurunan tingkat dari sel inflamasi dan air garam dalam sampel jaringan dibandingkan dengan kontrol. Peningkatan pembentukan kolagen juga diamati karena peningkatan hidroksiprolin dan konsentrasi heksosamin dan penurunan waktu reepitelisasi pada kelompok perlakuan (14 hari pada $20 \mathrm{mg} / \mathrm{kg}$ dan 13 hari pada $100 \mathrm{mg} / \mathrm{kg}$ vs. 17,7 hari pada kontrol) juga diamati. Pemeriksaan makroskopik menunjukkan fitidak dapat mengurangi luas permukaan ulkus pada kelompok calendula dibandingkan dengan kontrol dari 4 hari pasca cedera. menunjukkan hubungan dosis-efek nonlinier dengan efek maksimal pada kelompok uji konsentrasi gel 7\% dibandingkan dengan kelompok 5\% dan 10\%. Terdapat efektifitas maksimal pada kelompok $100 \mathrm{mg} / \mathrm{kgBB}$ dibandingkan dengan $20 \mathrm{mg} / \mathrm{kgBB}$ (Givol et al., 2019).
Kemudian terdapat penelitian eksperimental membandingkan kelompok perlakuan ekstrak Calendula officinalis 7,5\% ke kelompok kontrol pembalut larutan garam. Studi ini menunjukkan terdapat signifikasi pada pengurangan pada kelompok ekstrak calendula dibandingkan dengan kontrol secara signifikan pada 21 hari. Terdapat uji coba kontrol acak empat lengan pada pasien diabetes dengan ulkus kaki untuk pengurangan ukuran ulkus. Subyek ditugaskan untuk pengobatan dengan minyak ekstrak Calendula officinalis, terapi laser tingkat rendah, atau kombinasi keduanya, dibandingkan dengan kelompok kontrol perawatan standar $(\mathrm{n}=8)$ menerima pembersihan dan pembalut setiap hari. Pada penyelesaian studi tiga minggu, terdapat signifikasi untuk mengurangi area ulkus total dibandingkan dengan baseline untuk terapi laser rendah saja (7,98 vs 2,39 $\left.\mathrm{cm}^{2}, \mathrm{p}=0,04\right)$ dan untuk terapi laser rendah dalam kombinasi dengan minyak Calendula officinalis $\left(9,27\right.$ vs $2,57 \mathrm{~cm}^{2}$, $\mathrm{p}<0,003)$. Pada kelompok monoterapi minyak Calendula officinalis, ukuran total ulkus tidak signifikan, dan tidak dapat dikurangi dibandingkan dengan baseline (Givol et al., 2019).

\section{PEMBAHASAN}

Secara Percepatan re-epitelisasi pada pengobatan dengan ekstrak etanol dari Calendula officinalis telah dilaporkan in vivo pada tikus dan manusia. Reepitelisasi ditandai dengan proliferasi dan migrasi keratinosit ke dalam luka. Seringkali, uji awal digunakan untuk menstimulasikan peristiwa ini. Oleh karena itu, kami mempelajari dampak dari ketiganya Calendula officinalis ekstrak (HE, EE dan AE) pada migrasi keratinosit manusia yang diabadikan dalam percobaan pengujian awal. Luka 
yang diamati dengan pengobatan dengan tiga Calendula officinalis ekstrak pada konsentrasi $10 \mathrm{~g} / \mathrm{ml}$ setelah $12 \mathrm{jam}$, pada konsentrasi $50 \mathrm{~g} / \mathrm{ml}$ yang lebih tinggi, AE tidak menunjukkan efektifitas, sedangkan $\mathrm{HE}$ dan $\mathrm{EE}$ mengganggu penutupan luka. HGF digunakan sebagai kontrol positif, dan hasil ini signifikan secara statistik tidak bisa. Pengurangan efektifitas HE dapat dijelaskan dengan penurunan viabilitas sel yang ditunjukkan pada uji MTT setelah 12 jam inkubasi. Sebelumnya, glikosida seskuiterpen sitotoksik diisolasi dari ekstrak lipofilik Calendula officinalis dan terbukti mengurangi viabilitas sel (D'Ambrosio et al., 2015).

Oleh karena itu, terjadinya glikosida seskuiterpen di HE mungkin bertanggung jawab atas penurunan penutupan luka yang diamati. Menariknya, pengurangan efektifitas dari EE pada $50 \mu \mathrm{g} / \mathrm{ml}$ dalam uji awal tidak dapat sepenuhnya dijelaskan oleh berpengaruh pada viabilitas sel, karena EE pada $50 \mathrm{~g} / \mathrm{ml}$ hanya menyebabkan sedikit penurunan viabilitas keratinosit $(82,07 \% \pm 8,54)$ setelah 12 jam. Selain itu, kami mengevaluasi dampak triterpen pada proses reepitelisasi karena tidak dapat dikecualikan bahwa konsentrasinya di n-ekstrak heksanik mungkin terlalu rendah untuk menunjukkan efek apa pun. Fraksi triterpen itu purified dari n-ekstrak heksanik dari Calendula officinalis serta triterpenemonol dan karoten yang telah digambarkan sebagai konstituen dari Calendula officinalis juga diselidiki dalam uji awal (Nicolaus et al., 2017). Dari ester triterpen ini, dam marenediol II 3-miristat/palmitat (M6) belum dilaporkan untuk Calendula officinalis. Semua ester triterpen dan sebagian besar triterpenemonol menunjukkan kecenderungan untuk sedikit meningkatkan penutupan luka, sedangkan -karoten tidak memiliki efek samping. Selain itu, kesimpulan tidak dapat ditarik mengenai triterpen mana yang dapat mengerahkan aktivitas tertinggi. Selain itu, meskipun uji awal telah sering dilaporkan untuk menstimulasikan penutupan luka (Kramer et al., 2013), pengujian ini memiliki keterbatasan, karena interaksi kompleks dari sejumlah tipe sel dan faktor dalam proses re-epitelisasi tidak dapat direproduksi secara memadai dalam pengujian ini. Peningkatan kandungan kolagen I dan III pada luka dapat disebabkan oleh penurunan degradasi oleh proteolytic matrix metalloproteinases (MMPs) atau peningkatan sintesis kolagen pada luka.fibroblast (Rankin et al., 2013).

Oleh karena itu, kami mempelajari di satu sisi dampak dari calendula ekstrak pada enzim pendegradasi kolagen dalam in vitro uji penghambatan kolagenase. Kolagenase bakteri diisolasi dari Clostridium histolyticum digunakan sebagai enzim target karena kemampuannya yang sama untuk mendegradasi kolagen sebagai matriks metaloproteinase (MMPs) dari suatu vertebrata. Selain itu, kami mempelajari efektifitas dari Calendula officinalis ekstrak pada in vitro kandungan kolagen dalam kulit manusia fibroblas menggunakan kit uji kolagen Sircol, yang secara spektrofotometri menentukan kolagen terlarut dalam supernatan kultur sel (Lareu et al., 2010). Ekstrak etanol (EE) serta ekstrak air (AE) secara signifikan mengurangi aktivitas kolagenase dibandingkan dengan kontrol pelarut dengan cara yang bergantung pada konsentrasi, tetapi penghambatannya hanya sedang. Konsentrasi AE 500 g/ml mengurangi aktivitas kolagenase menjadi 45,34\% \pm 1,96 (SEM), sedangkan konsentrasi EE yang lebih rendah, $100 \mathrm{~g} / \mathrm{ml}$, 
menyebabkan penurunan serupa $(44,48 \% \quad \pm \quad 3,75 \quad($ SEM $))$. Karena masalah kelarutan, n-ekstrak heksanik tidak dapat diuji dalam uji penghambatan kolagenase. Komite Produk Obat Herbal (HMPC) dan Komisi E menyetujui persiapan: Calendula officinalis untuk pengobatan luka kecil dan penyembuhan luka yang buruk, yang juga ditandai dengan berkurangnya pembentukan jaringan granulasi. Selama fase ini komponen matriks ekstraseluler (ECM), seperti kolagen, disintesis untuk ruang luka. Beberapa hasil dari penelitian adalah lipofilik dan alkoholik Calendula officinalis ekstrak meningkatkan sintesis kolagen (Nicolaus et al., 2017).

Secara keseluruhan ekstrak Calendula dikaitkan dengan signifikan secara statistik dapat meningkatkan penyembuhan luka di kulit sesuai dengan hasil yang diukur. Penilaian histologis menunjukkan, peningkatan angiogenesis ( 2 vs 1 pembuluh darah perfitua; 8 vs. 4,8 putaran kapal) (Dinda et al., 2016) dan komposisi kolagen yang lebih padat (Parente 2012), dalam jaringan granulasi membentuk kelompok perlakuan calendula dibandingkan dengan kontrol. Kelompok perlakuan juga menunjukkan hasil penurunan tingkat dari sel inflamasi (makrofag 1,8 vs 8,8; 0,8 vs 2 sel plasma; 12,2 vs 22 limfosit) dan air garam dalam sampel jaringan dibandingkan dengan kontrol. Peningkatan pembentukan kolagen juga diamati karena peningkatan hidroksiprolin $(9,87 \mathrm{vs} 4,75 \mathrm{mg} / \mathrm{g}$ berat kering jaringan setelah 15 hari) dan konsentrasi heksosamin (20,7 vs 12,8 $\mathrm{mg} / \mathrm{g}$ berat kering jaringan setelah 5 hari) (Preethi, 2009) dan penurunan waktu reepitelisasi pada kelompok perlakuan (14 hari pada $20 \mathrm{mg} / \mathrm{kg}$ dan 13 hari pada $100 \mathrm{mg} / \mathrm{kg}$ vs. 17,7 hari pada kontrol) juga diamati. Pemeriksaan makroskopik menunjukkan dapat mengurangi luas permukaan ulkus pada kelompok Calendula dibandingkan dengan kontrol dari 4 hari pasca cedera. Shafie, dkk menunjukkan hubungan dosis-efek nonlinier dengan efek maksimal pada kelompok uji konsentrasi gel $7 \%$ dibandingkan dengan kelompok $5 \%$ dan $10 \%$. Ditemukan efektifitas maksimal pada kelompok $100 \mathrm{mg} / \mathrm{kgBB}$ dibandingkan dengan $20 \mathrm{mg} / \mathrm{kgBB}$. Peran dari Calendula dalam penyembuhan luka akut terutama dieksplorasi dalam studi model hewan in vivo, dengan hanya satu uji klinis menilai luka akut. Semua model hewan yang digunakan adalah hewan pengerat, memberikan homogenitas desain penelitian. Penelitian pada hewan memberikan bukti moderat untuk pemulihan yang lebih baik dari dalam fase inflamasi dan peningkatan produksi jaringan granulasi pada kelompok perlakuan ekstrak Calendula. Terdapat dijelaskan oleh antiinflamasi dan ditingkatkan aktivasi dan migrasi broblas sifat Calendula, seperti yang diamati dalam studi in vitro. Kombinasi dari efek ini memungkinkan penyembuhan yang lebih baik untuk luka pada kulit (Givol et al., 2019).

Studi hewan in vivo menunjukkan bahwa ekstrak Calendula dapat meningkatkan penyembuhan kulit setelah luka bakar dan memberikan efek perlindungan dari kerusakan radiasi. Penting untuk dicatat bahwa dalam studi model hewan vivo, ekstrak calendula diberikan secara oral dengan dosis pertama sebelum terbakar. Oleh karena itu, studi ini menilai profilaksis daripada efek terapeutik. Hasil yang lebih baik dari ekstrak calendula dalam studi ini dapat dikaitkan dengan antioksidannya dan efek proangiogenik, 
yang mempengaruhi zona luka bakar stasis. Dalam uji klinis, aplikasi ekstrak Calendula topikal pada luka bakar menunjukkan hasil yang beragam. Hasil menunjukkan tidak ada efek calendula pada penyembuhan luka bakar derajat kedua sampai dengan luka bakar derajat ketiga. Namun, penelitian ini tidak mencapai ukuran sampel yang diusulkan dan dihentikan karena perbedaan kultus dalam perekrutan dan karenanya hasil nol mungkin karena ukuran sampel yang lebih kecil dari yang diharapkan (Shafeie, 2015).

Kemudian ditemukan hasil dari penelitian eksperimental membandingkan kelompok perlakuan ekstrak calendula 7,5\% $\quad(n=21) \quad$ ke kelompok kontrol pembalut larutan garam $(n=13)$. Studi ini menunjukkan terdapat signifikasi pada pengurangan pada kelompok ekstrak Calendula dibandingkan dengan kontrol (pengurangan $41 \%$ pada luas permukaan ulkus total vs. $14 \%, \mathrm{p}<$ $0,05)$ pada 21 hari. Uji coba kontrol acak empat lengan pada pasien diabetes dengan ulkus kaki untuk pengurangan ukuran ulkus. Subyek ditugaskan untuk pengobatan dengan minyak ekstrak calendula $(\mathrm{n}=8)$, terapi laser tingkat rendah $(\mathrm{n}=8)$, atau kombinasi keduanya $(\mathrm{n}=8)$, dibandingkan dengan kelompok kontrol perawatan standar (n $=$ 8) menerima pembersihan dan pembalut setiap hari. Pada penyelesaian studi tiga minggu, ada terdapat signifikasi yang mengurangi area ulkus total dibandingkan dengan baseline untuk terapi laser rendah saja $(7,98$ vs $2,39 \mathrm{~cm} 2, \mathrm{p}=0,04)$ dan untuk terapi laser rendah dalam kombinasi dengan minyak Calendula $(9,27$ vs $2,57 \mathrm{~cm} 2, \mathrm{p}$ $<$ 0,003). Pada kelompok monoterapi minyak calendula, ukuran total ulkus tidak terdapat signifikasi dapat dikurangi dibandingkan dengan baseline (Givol et al., 2019).

Uji klinis acak yang dilakukan menilai efek Calendula pada dermatitis pascaradiasi. Studi berbeda dalam salep mereka dikelompok eksperimen dan di kelompok kontrol mereka. Salep Calendula terbukti lebih unggul daripada Trolamin merancang lensa yang dapat menurunkan defokus hiperopik perifer secara individual dan untuk menganalisis manfaat lensa ini dalam dalam pencegahan dermatitis parah, bagaimanapun, itu tidak ditemukan berbeda dari efek krim pelembab dasar aqua. Kedua penelitian memiliki ukuran sampel yang besar (>100 di setiap kelompok perlakuan), dan mereka menggunakan metode penilaian skala kelompok onkologi terapi radiasi (RTOGS). Meskipun kesamaan dan kualitas tinggi dari dua desain penelitian, hasilnya memberikan kesimpulan yang berbeda. Ketika membandingkan kelompok perlakuan Calendula antara kedua penelitian, ada perbedaan besar dalam kejadian dermatitis akut pasca radiasi yang parah (41\% dan 23\%).

Perbedaan hasil mungkin karena bias pengamatan sejak evaluasi dermatitis akut dilakukan dengan RTOGS, yang subjektif, dan dalam setiap studi pengasuh yang berbeda melakukan evaluasi, dengan kemungkinan reliabilitas antar-penilai yang rendah. Pembahasan untuk perbedaan hasil studi adalah variasi dalam pendekatan tindak lanjut. Dalam tindak lanjut dilakukan setiap minggu, dilakukan hanya tiga kali (dalam minggu pertama dan terakhir dan satu minggu setelah penghentian pengobatan radiasi). Pembahasan lain yaitu adalah terdapatnya perbedaan salep Calendula yang digunakan dalam kedua penelitian 
atau perbedaan teknik radiasi yang digunakan. Ini berbeda kultus untuk menilai efek ekstrak pada dermatitis pasca radiasi akut dari studi ini (Shafeie, 2015).

\section{SIMPULAN}

Ada beberapa bukti keefektivitasan dari penggunaan ekstrak Calendula officinalis untuk manajemen penyembuhan luka di kulit. Data yang disajikan dalam ulasan ini mendukung studi lanjutan tentang penggunaan salep yang mengandung ekstrak Calendula officinalis selama penyembuhan luka. Calendula officinalis dapat mencegah komplikasi luka karena mengandung metabolit sekunder, yang dapat mendukung penyembuhan luka. Karena terbatasnya jumlah uji klinis dan perbedaan metodologisnya, ada kebutuhan untuk uji coba kontrol acak prospektif besar yang dirancang dengan baik dengan ukuran hasil yang divalidasi dan konsisten untuk menetapkan efektifitas khasiat ekstrak Calendula officinalis pada penyembuhan luka.

\section{DAFTAR PUSTAKA}

Colombo, E., Sangiovanni, E., D’Ambrosio, M., Bosisio, E., Ciocarlan, A., Fumagalli, M., Guerriero, A., Harghel, P., Dell'Agli, M. (2015). A bioguided fractionation to assess the inhibitory activity of Calendula officinalis L. on the NF- $\kappa \mathrm{B}$ driven transcription in human gastric epithelial cells. Evid. Based Complement Alternat. Med. 2015, 1-8. http://dx.doi.org/10.1155/2015/72 $\underline{7342}$.

Dinda M., Mazumdar S., Das S., Ganguly D., Dasgupta U.B.,
Dutta A., Jana K., Karmakar P. (2016). The Water Fraction of Calendula officinalis Hydroethanol Extract Stimulates In Vitro and In Vivo Proliferation of Dermal Fibroblasts in Wound Healing. Phytother Res. Oct;30(10):1696-1707. doi: 10.1002/ptr.5678. Epub $2016 \mathrm{Jul}$ 18. PMID: 27426257.

Izadi K., Ganchi P. (2005). Chronic wounds. Clin Plast Surg; 32:20922.

doi:

10.1016/j.cps.2004.11.011.

PMID: 15814118.

Givol, O., Kornhaber, R., Visentin, D., Cleary, M., Haik, J., \& Harats, M. (2019). A systematic review of Calendula officinalis extract for wound healing. Wound Repair and Regeneration, 27(5), 548-561.

https://doi.org/10.1111/wrr.12737

Kramer, N., Walzl, A., Unger, C., Rosner, M., Krupitza, G., Hengstschläger, M., Dolznig, $\mathrm{H}$. (2013). In vitro cell migration and invasion assays. Mutat. Res. 752 , 10-24. http://Dx.doi.org/10.1016/j.mrrev .2012.08.001.

Lareu, R.R., Zeugolis, D.I., Abu-Rub, M., Pandit, A., Raghunath, M. (2010). Essential modification of the Sircol Collagen Assay for the accurate quantification of collagen content in complex protein solutions. Acta Biomater. 6 , 3146-3151. http://Dx.doi.org/10.1016/j.actbio .2010 .02 .004 .

Leach MJ. (2008). Calendula officinalis and Wound Healing: A Systematic Review. Wounds. 
Aug;20(8):236-43. PMID: 25941793.

Muley B, Khadabadi S, Banarase N. (2009). Phytochemical constituents and pharmacological activities of Calendula officinalis Linn (Asteraceae): a review. Trop J Pharmaceut Res; 8:455-65. doi: 10.4314/tjpr.v8i5.48090.

Nicolaus, C., Junghanns, S., Hartmann, A., Murillo, R., Ganzera, M., \& Merfort, I. (2017). In vitro studies to evaluate the wound healing properties of Calendula officinalis extracts. Journal of Ethnopharmacology, 196(November 2016), 94-103. https://doi.org/10.1016/j.jep. 20 $\underline{16.12 .006}$

Parente, L.M., Lino Júnior Rde, S., Tresvenzol, L.M., Vinaud, M.C., de Paula, J.R., Paulo, N.M. (2012). Wound Healing and Anti-Inflammatory Effect in Animal Models of Calendula officinalis L. Growing in Brazil. Evid Based Complement Alternat Med. 2012:375671. doi: 10.1155/2012/375671. Epub 2012 Jan 24. PMID: 22315631; PMCID: PMC3270572.

Preethi, K.C., Kuttan, R. (2009). Wound healing activity of flower extract of Calendula officinalis. J Basic Clin Physiol Pharmacol. 20(1):73-9. doi: 10.1515/jbcpp.2009.20.1.73. PMID: 19601397.

Rankin, A.C., Hendry, B.M., Corcoran, J.P., Xu, Q. (2013). An in vitro model for the profibrotic effects of retinoids: mechanisms of action. Br. J.
Pharmacol. 170, 1177-1189. http://dx.doi.org/10.1111/bph.1 2348.

Re TA, Mooney D, Antignac E, Dufour E, Bark I, Srinivasan V, Nohynek G. (2009). Application of the threshold of toxicological concern approach for the safety evaluation of calendula flower (Calendula officinalis) petals and extracts used in cosmetic and personal care products. Food Chem Toxicol. Jun;47(6):1246-54. doi: 10.1016/j.fct.2009.02.016. Epub 2009 Feb 26. PMID: 19249334.

Shafeie, N., Naini, A. T., \& Jahromi, H. K. (2015). Comparison of different concentrations of calendula officinalis gel on cutaneous wound healing. Biomedical and Pharmacology Journal, 8(2), 979-992. https://doi.org/10.13005/bpj/85 $\underline{0}$

Velnar T, Bailey T, Smrkolj V. (2009). The wound healing process: an overview of the cellular and molecular mechanisms. J Int Med Res; 37: 1528-42. doi: $10.1177 / 147323000903700531$ 
Jurnal Penelitian Perawat Profesional, Volume 3 No 3 Hal 461 - 470, Agustus 2021 Global Health Science Group 